\title{
Information-Conneted Approach in Identifying Capital Market Crime at Information Technology Era
}

\author{
Suwinto Johan ${ }^{1,2 *}$ Ariawan Ariawan ${ }^{2}$
}

\author{
${ }^{1}$ Faculty of Business, President University, Cikarang, Bekasi, Indonesia \\ ${ }^{2}$ Magister Ilmu Hukum, Faculty of Law, Tarumanagara University, Jakarta, Indonesia \\ *Correspondence author. Email: suwintojohan@gmail.com
}

\begin{abstract}
Digital development has inferences for financial transactions, especially in capital market. Digital development creates stock transactions exceed cross-national. Digital development has few side positive and negative effects. One of the effects is insider information. Insider information is considered as cime in capital market. Investors use insider information to make profits. This paper uses the normative judicial method and a comparative law method. This paper studies capital market law regarding insider trading in Japan, Switzerland, Indonesia and Singapore. This research aims to define the definition of insider trading in digital era. The definition of insider trading is benchmarked on the regulations and laws of the four countries. This study summarizes that insider trading should be based on information connected following development in technology development. The law needs to be amended regarding insider trading based on informationconnected approach.
\end{abstract}

Keywords: Capital market, insider trading, information connected, law

\section{INTRODUCTION}

Indonesia's President Joko Widodohas stated that the COVID-19 vaccine will be delivered for free for all Indonesians citizen [1]. The Indonesian government holds majority shares in 2 listed pharmaceutical corporations. Kimia Farma and Indofarma are two companies whose stakes are held by the governemt of Indonesia. Kimia Farma registered on the Indonesia Stock Exchange (IDX), namely as KAEF.

Joko Widodo stated the public of the free COVID-19 vaccine on Wednesday, 16 December 2020. On 16 December 2020, at 11.44 AM, one of Joko Widodo's son, Kaesang Pangarep tweeted \$ KAEF? on his Twitter account. On the same date, at 1.19 PM, Kaesang Pangarep tweeted, "Something will fly, although it is not an airplane." At 1.31 PM, Kaesang Pangarep tweeted again,

\begin{abstract}
"Something is flying right there." President Joko Widodo announced that Indonesia would offer free COVID-19 vaccines to Indonesians. Kimia Farma's shares shot up following the news [2].

Kimia Farma's stock price hike $2.54 \%$ to 4,440 IDR/share following the statement by Joko Widodo. The Indonesian stock exchange's composite stock price index hike $1.65 \%$ to reach 6,109 at 2.43 PM [3]. The stock price of KAEF cut by $2.5 \%$ till 10.00 AM. After Kaesang's tweet, the stock price hike $4.66 \%$ and exceeded its morning opening value. These stock changes are exposed in Table 1 . Was the Joko Widodo's son's Kaesang tweet a coincidence, or did he aware about the free vaccine info earlier? Did Kaesang's tweet interrupt the information material and insider information criteria based on capital market law regarding insider trading? [4]
\end{abstract}

Table 1 The changes of KAEF stock's prices as of September 16, 2020

\begin{tabular}{|c|c|c|}
\hline $\begin{array}{c}\text { Western } \\
\text { Indonesia Time }\end{array}$ & Share's Price of KAEF & Changes in Share Price \\
\hline 09.00 & 4.400 & $-2.05 \%$ \\
\hline 09.30 & 4.310 & $-0.46 \%$ \\
\hline 10.00 & 4.290 & $+4.66 \%$ \\
\hline 11.30 & 4.490 & $-1.11 \%$ \\
\hline 14.00 & 4.440 & $0.00 \%$ \\
\hline 14.30 & 4.440 & $-0.23 \%$ \\
\hline 15.00 & 4.430 & \\
\hline
\end{tabular}

Source: [5] 
Carllyle Group, a private equity corporation, discharged one of its senior executives in Indonesia because he was involved in insider trading on the Indonesian stock exchange (IDX). The Monetary Authority of Singapore (MAS) has fined of USD 316,000 for an insider trading deal in Bank Danamon (BDMN) stock by Rajiv Louis. Louis had non-public material information from the intended acquisition of Bank Danamon by the Development Bank of Singapore (DBS) Group, Singapore. Rajiv Louis used a nominee stock account to buy shares in Bank Danamon (BDMN), Indonesia. Insider trading can take cross borders. Louis received a judgement while working for Carlyle, a private equity firm established in the United States of America. This is shown in Figure 1. Shinsuke Tsuoka, a former senior executive of a rental storage firm based in Japan, called Palma, made insider trading with his friend, called Hirayama. The two gentlemen purchased Palma stock prior the proclamation that the Japan Post Group (JPG) deliberated to purchase a 20 percent stake in Palma. Hirayama got the acquisition news from Tsuoka. Japanese authorities enforced criminal charges on Tsuoka and Hirayama.

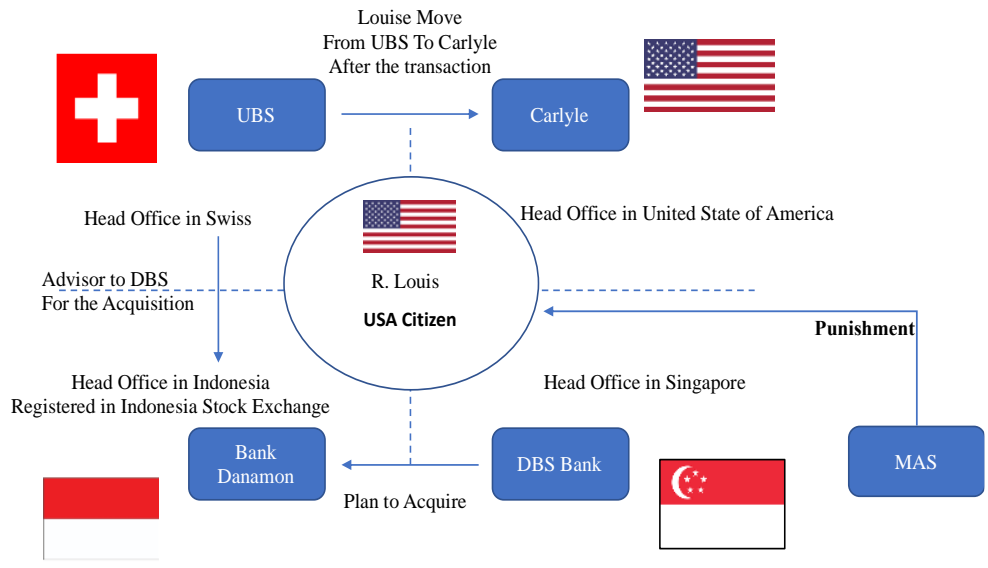

Figure 1 Louis' Insider Trading Deals

\section{BACKGROUND}

Study on insider trading connecting parties outside the firm or outsider is still scarce. This research objective to study the description of insider trading in four nations, namely three nations that have developing capital markets, Switzerland, Singapore, and Japan, and one emerging capital market, Indonesia. Indonesia is a member of G-20 and will developed to be 5th largest economy in the following five years. This research will recommend the best description of insider trading. This description of insider trading will be accustomed to the present development of digital technology era. Indonesia has more than 197 million active users of mobile phone. The number of stock retail investors extend 1,503,682 accounts by end of 2020 in Indonesia.

This research has the following research questions: How is the description of insider trading in other nations? How should we adjust insider trading description to costume today's digital technology era?

Based on the Indonesian Capital Market Law, material information is information or facts that can distress the stock price of a publicly registered company or may encourage shareholders' or investors' judgements to expressing investment decisions. A public listed company that does not publish material information may be subject to sanctions in the form of fines and sentences [6]. Transparency is one of the principles of good corporate governance (GCG). This is also stipulated in the laws of capital market. Information disclosure in the capital market is unqualified [7]. The capital market is outlined as a get-together place for sellers and buyers to do securities dealings. Capital market activities need legal instruments that rule them to track regularly and fairly for all parties in capital market transaction [8].

The principle of transparency in the capital market states that issuers and capital market supporting professionals must express information regarding material information truthfully, and adequately so that this material information distresses investors' judgments to invest in the capital market [9].

Based on the Stock and Exchange Commission (SEC)'s of United State, Rule 10b-5, insider trading can be conveyed based on the tipper-tippee theory. The authority needs to show that the information provider (tippee) profits from the information delivered, and the tipper knows the profit of the information gained [10].

The implementation of corporate governance is still fragile in public companies in emerging countries, as shown by the behavior of taking gains by exploiting weaknesses in laws and weaknesses in fines in capital market laws [11]. Investors are still trying to get short-term gains in emerging markets. Misuse of corporate governance and compliance is a common manifestation. Modern corporate governance standards and principles are vital in developing countries such as Indonesia, Bangladesh, China, India, Vietnam, Myanmar, and others [12]. 
Insider trading is a crime in the capital market law that is not easy to verify, even in industrialized countries such as United States. It is challenging to show the practice of insider trading misconduct [13]. Inside traders can make up to $35 \%$ gain for 21 days; information is spread via social networking. Spreading of information through social networks can surge efficiency in information spreading [14]. The disclosure of information on prices and volumes in response to the news has publicized implications for securities transaction [15].

\section{METHODS}

This research technique is a normative juridical method. The research approach used is a statute approach by describing the existing laws and regulations relevant to the problems studied, especially the substance related to insider trading concerns on the capital market. Another approach used is the comparative approach, which compares laws and regulations relating to insider trading in Switzerland, Singapore, Japan, and Indonesia [16]. This study also examines digital or technology factors in stock or bond trading and information spreading.

\section{RESULTS AND DISCUSSION}

The investment goals to gain maximum yields with a short period of time. Capital market investment is an investment that is contemplated easy to enter and exit from the investment market. Capital market investments consist of hundreds to millions of people. All investors will exploit following the info available in the market, to purchase or sell securities. Information is vital for all parties involved in capital markets. Speed of decision making grounded on available information will deliver an advantage. Postponements in obtaining material information will be useless to an investor. Information is critical for an investor in capital market.

Many investors will effort to acquire imperative info on a firm. The information has two outcomes, namely mounting gains or cutting losses. The spreading of information that is not equalized will produce the market to be inadequate in competition.

\subsection{Japan's Law}

Insider trading is a violation of law in Japan per the Financial Instruments and Exchange Act (FIEA) Articles 166 and 167. FIEA regulates that insider trading is a single person or party in a firm (corporate insider) who has material non-public information or knowledge and cannot handle transactions. Securities of related companies, until the information is open to the public. The definition of a person or party in the firm is an employee, whether a full time, contract, part-time employee or someone who has the right to inspect the company, including shareholders who have shares of more than $3 \%$, a public officer, a party who will settle, negotiations with the related public company. This employee gets information regarding this company's non-public information. A person who acquires non-public information from a corporate insider can also be classified as insider trading.

A person can use non-public information if the information has been publicized through the channels for 12 hours, the capital market website has distributed this non-public information, or the annual report has been shared to the public. Japanese regulations have permitted the usage of non-public information as long as it has been published. This procedure will make it easier to practice non-public information. A period of 12 hours can be construed as the next business day. Typical hours are eight working hours.

Individuals can be condemned to five years in prison or a fine of up to five million yen, or both. A company will be punished up to 500 million yen. Besides, there is an administrative monetary penalty for the benefits obtained [17]. Japan provides a 5-year prison sentence as a criminal penalty.

\subsection{Singapore's Law}

Insider trading is a matter concerning the firm's future, carried out by somebody at the firm or other party who owns non-public info. The insider trading case has two approach. In the traditional approach, insider trading is carried out by firm managements and staffs, such as directors, corporate secretaries, managers and staffs. They do stock transactions for gain by using non-public info. A non-traditional case approach, insider trading involves second-level parties in exploiting non-public information. The Monetary Authority of Singapore (MAS) implements an information connected-approach. This approach is dissimilar from the previous approach, namely, person or people-connected approach. The authorities do not prerequisite to relate the connection between the person who has the information and the person who creates the transaction. Information-connected will be able to include parties outside the firm who advantage from insider information. Based on the Securities and Futures Act (SFA) section 218, a person can be considered as insider transaction if a person has a connection with a company, has info about that firm, has non-public info, that info has a significant consequence on the value of marketable securities of the company, knowing that the information is not public info and the related person realizes that if the public recognizes this non-public information, it will affect the value of securities of the firm. If a person congregates all of these requirements, they can be categorized as a violator. Based on section 232 (1), SFA, MAS can enforce a fine on insider transaction. The court can sentence a fine for this violation. The penalty is three times of profit gained or loss avoided if the perpetrator has no gain or loss, the offender will be penalized between $\mathbf{S} \$ 50,000$ to $S \$ 2,000,000$. Courts can sentence sentences of up to S\$250,000 or maximum imprisonment of seven years or both. This penalty is based on section 218, SFA. Singapore stretches a 7-year criminal punishment. 


\subsection{Indonesian Laws}

Insider trading based on Article 95 of the Indonesian Capital Market Law No. 8 Year 1995 is an insider of an issuer or public firm who has non-pubilc information which is forbidden from ordering the securities of the public company or Issuer, or other companies that conduct transactions with the public company or issuer concerned. Insider in a firm means board of commissioners, board of directors, or employees of a public company or issuer; significant or controlling shareholders of the public company or issuer; a person who due of his position or occupation or due of his business connection with the public company or issuer consents that the person to get inside information; or a party which within the last 6 (six) months is no longer the party as mentioned to previously. A business connection is a business relationship or partnership, including relationships between customers, suppliers, contractors, and creditors. Inside information is substantial info that is owned by insiders which are not yet presented to the public. Article 97 of the Capital Market Law orders that any party that attempts to acquire inside information from insiders against the law and then achieves it is subject to the same exclusion as the exclusion that pertains to insiders, any party who tries to get inside information and then gets it without fighting the law is not subject to restrictions that apply to insiders as long as the public company or issuer offers the information without restriction. Parties who breach the provisions of articles 95, 96, and 97 can be subject to a maximum sentence of ten years and a maximum fine of 15 billion rupiah. The parties in question can comprise of individuals or firms. Indonesia provides maximum detention of ten years prison for insider trading.

\subsection{Swizertland's Law}

As of July 1, 1988, Switzerland has new laws regarding insider transactions (Article 161 of the Federal Criminal Code). Insider information is endangered if it can be categorized as a commercial undisclosed. Penalties can be forced if there is a statement of info by somebody inside to a third party and does not include info by parties inside the firm. This regulation took 15 years to be approved. Neither the business's parties nor the receiving party of information can consume the information to profit through securities dealings to obtain financial gains. Insiders are firm representatives such as directors, general managers, managers, auditors, staffs or people who act as officers or advisors for the firm. This law also standardizes insiders, including officials from civil servants, government agencies, or someone who assists their activities. Besides, tippees are outsiders who obtain confidential information from insiders, either directly or indirectly. Those who receive info know that this info is unlawfully revealed. A transaction can be considered as insider trading if an insider or tippee recognizes that the info is trustworthy and knows that the information has a considerable result on the security market value. Insiders intentionally use the information to benefit or stipulate information to parties when it is deliberated to gain profit. Article 161 does not indicate civil fines. Corrective action is compulsory on the perpetrator, requiring the withdrawal of the transaction and compensation [18].

\subsection{Definition of Insider Trading in Digital Era}

The digital age has made massive information broadcasting. Information concerning the firm also spreads rapidly. Good news and bad news easily feast through numerous social medias. Dispersed information can be in the form of non-public information. False non-public information is considered as a hoax. If the information is intentionally dispersed with a bad objective.

Regulation of non-public information and insider trading can be done through an information-connected approach. Information connected approach is dissimilar from the people-connected approach that is currently in consequence. Insider trading today is grounded on people having non-public information or insider information on public companies. People-connected approach focuses on people who nurse the information.

Information-connected approach focuses on information that is owned by somebody, so that person makes transactions and gets benefit it. A photocopy staff in the general affair departement, identifies non-public information and proceeds advantage of securities transactions, then the staff can be considered to insider trading or insider transaction sanctions. A friend absorbs of a friend's telephone conversation at a restaurant. The person purchases shares and takes benefit from the transaction of the shares, so the person who puchases the stocks can be sentenced.

This study substitutes the definition of insider trading into non-public information owner. The definition of nonpublic information owner trading is the trading of securities by someone who owns non-public information and gains from the securities transaction. This person can be an insider or anyone who obtains non-public information and uses it for profit. The authority imposes sanctions in the amount several times over for profits gained or losses minimized. Sanctions are given to information recipients and information givers. Criminal sanctions should be not given to those involved. Only civl sanctions could be given.

\section{CONCLUSIONS}

Transactions in the capital market prerequisite information. Information will assist investors in formulating investment decisions. Non-public information will advantage those who obtain it. Non-public investors can gain or reduce a loss of an investment. Technology has made information spreading not only to people inside the firm, but also to people outside the firm. Technology has also made stock transactions easier and has massively crossed-border. The determination of insider trading in the 
digital or technology information era must use the information-connected approach, not based on the peopleconnected approach. Non-public information can easily be circulated through social media. Information is no longer expressed by word of mouth but through posting on social media. The information-connected approach becomes suitable. The study will provide contribution to the regulators for revisions to the description of insider trading and modify to the sanctions imposed. Capital market transactions are civil transactions, so it is not considered as criminal crimes. Fines can be assumed in the form of compensation. Fines can also be imposed on a person by being exposed of his/her rights as an investor in the capital market or becoming a management of a public firm.

\section{REFERENCES}

[1] A. Syakriah, "Jokowi announces 'free' Covid-19 vaccines for all". Retrieved from https://www. thejakartapost.com/news/2020/12/16/jokowi-announces -free-covid-19-vaccines-for-all.html dated (2020, December 18).

[2] Detik Finance. "Kaesang Dituding Insider Trading Ini Kata BEI". Retrieved from https://finance. detik.com/bursa-dan-valas/d-5300131/kaesang-dituding -insider-trading-ini-kata-bei dated (2020, December 18)

[3] S. Taher, "Keasang Cuit Saham KAEF Sebelum Jokowi Umumkan Vaksin Gratis". Downloaded from https://www.cnbcindonesia.com/market/202012161438 04-17-209544/kaesang-cuit-saham-kaef-sebelumjokowi-umumkan-vaksin-gratis dated (2020, December 18)

[4] Detik Finance. "Kok Bisa Tahu Saham KAEF Bakal Terbang Kaesang Insider Trading". Retrieved from https://finance.detik.com/bursa-dan-valas/d5300050/kok-bisa-tahu-saham-kaef-bakal-terbangkaesang-insider-trading dated (2020, December 18).

[5] Yahoo Finance retrieved from https://finance. yahoo.com/quote/KAEF.JK/ dated December 20, 2020

[6] H. Agusta, "Pertanggungjawaban Khpm Dalam Proses Ipo Jika Terdapat Fakta Material Yang Tidak Diungkap". Masalah-Masalah Hukum 49(1) (2020) 4860. https://doi.org/10.14710/mmh.49.1.2020.48-60

[7] E. Herlina, "Implementasi Prinsip Transparansi Sebagai Salah Satu Prinsip-Prinsip Good Corporate Governance dalam Pasar Modal". Pemuliaan Hukum 1(1) (2018) 1-14.

[8] I. N. Suardana, N.L. Mahendrawati, \& N. G. K. S. Astiti, "Perlindungan Hukum Terhadap Investor
Berdasarkan Prinsip Keterbukaan oleh Emiten di Pasar Modal". Jurnal Analogi Hukum 2(2) (2020) 182-186. https://doi.org/10.22225/ah.2.2.1918.182-186

[9] I. G. A. Wisudawan, Penerapan "Sanksi Hukum Terhadap Profesi Penunjang Pasar Modal Atas Informasi yang Tidak Benar dan Menyesatkan dalam Pembuatan Prospektus Menurut Undang-Undang No 8 Tahun 1995 Tentang Pasar Modal". Jurnal Jatiswara 3(1) (2015) 45-70. Retrieved from http://jatiswara.unram.ac.id/index.php/js/article/view/90

[10] K. E. Woody, "The New Insider Trading”. SSRN Electronic Journal 2019 https://doi.org/10.2139/ssrn. 3474570

[11] A. Sya'bani, "Minority Shareholders' Protection". Indonesia Law Review 4(1) (2014)

[12] P.M. Dat, N.D. Mau, B.T.T. Loan, \& D.T.N. Huy, "Comparative China Corporate Governance Standards After Financial Crisis, Corporate Scandals and Manipulation". Journal of Security and Sustainability Issues 9(3) (2020) 931-941. https://doi.org/10.9770/ jssi.2020.9.3(18)

[13] Y. Amelia, "Insider Trading in Capital Market (Kajian Literatur Empiris Akuntansi Berbasis Pasar Modal)". Jurnal Bisnis Darmajaya 2(1) (2016) 125140.

[14] K.R. Ahern, "Information networks: Evidence from illegal insider trading tips". Journal of Financial Economics 125(1) (2017) 26-47. https://doi.org/ 10.1016/j.jfineco.2017.03.009

[15] J. L. Rogers, D. J. Skinner, \& S.L.C. Zechman, "The role of the media in disseminating insider-trading news". Review of Accounting Studies 21(3) (2016) 711-739. https://doi.org/10.1007/s11142-016-9354-2

[16] L. Sautunnida, "Urgensi Undang-Undang Perlindungan Data Pribadi di Indonesia: Studi Perbandingan Hukum Inggris dan Malaysia". Kanun Jurnal Ilmu Hukum 20(2) (2018) 369-384. https:// doi.org/10.24815/kanun.v20i2.11159

[17] Department of Market Surveillance and Regulatons, JPX, "Brief Summary of Insider Trading Regulations in Japan”, On February 2016.

[18] C. Meier-Schatz, \& K. Larsen, Swiss "Securities Regulation and Capital Market Law: A Comprehensive Overview. Denver" Journal of International Law \& Policy 18(3) (2020) 7. 